\title{
Optimization of Youtube: Media Based on Inclusive Education Anthropological Improving Learning in History Education Department
}

\author{
IkaPurnamasari $^{1}$, Ida Liana Tanjung ${ }^{2}$, Tappil Rambe ${ }^{3}$ \\ \{ikapurnamasari007@gmail.com ${ }^{1}$, Idatanjung78@gmail.com ${ }^{2}$ tappilrambe98@gmail.com ${ }^{3}$ \} \\ Department of History, Faculty of Social Sciences, Universitas Negeri Medan, Indonesia ${ }^{1,2,3}$
}

\begin{abstract}
In Higher Education, the ignition of the theoretical learning objectives of students must be Followed by mastery of good skills and affective skills. The problem faced by students is the lack of students' learning ability to upload videos to Youtube as a learning medium. The general objective of this research is to develop Youtube as a learning medium. The specific objectives of this study are (1) optimizing video-based educational videos via Youtube, (2) analyzing student enthusiasm for learning using websites, and (3) increasing student activities via the internet. This research activity optimization through the implementation stage in the form of (a) designing learning videos anthropology (b) designing websites (c) uploading videos on websites (d) socializing websites objects namely historical research on education students. The results of this study are the Increased ability of students to upload videos to Youtube learning based on educational videos. Apart from the advantages and disadvantages of this Youtube media can be a theoretical concept to be more realistic visualization because of the effect it has.
\end{abstract}

Keywords: Youtube, educational media, Optimization, Learning.

\section{Introduction}

Advances in technology are inevitable in this life, because of technological advances will be run under the progress of science. Each innovation was created to provide positive benefits for students [4]. Advances in technology now one of her social media such as Youtube. Education is the most important thing that must be owned, it is understood and meant for every human being. Education, in general, has meaning in the life of a process to develop themselves each individual to live and carry out the work. Education can be obtained anywhere, most people experience in everyday life can be used as education, because it can change a person to become better. The college became a place of providing education to individuals who seek knowledge. Department of the History Education State University of Medan is one place to get an education. One of the subjects in this course is a course where the anthropology this course as an auxiliary science that is in need. Because in reviewing the historical sources need the help of other supporting science. 
Learning Anthropology is the study of man both in terms of culture, behavior, diversity, and others. The culture in Indonesia is very diverse, spread from Sabang to Merauke. This culture includes tangible cultural heritage such as historic relics such as temples, artifacts, traditional houses and so on. Meanwhile, intangible culture in the form of non-material culture such as dance, music, singing, traditional cuisine. Then, in this case, the students in fulfilling the task of optimizing Youtube media. Because in the course Anthropology No matter who talks about culture. Universally according to Cluckhon that there are seven elements of culture that we need to know and learn in-depth. In this case, Suparlan (1980) in Keesing expressed the opinion that the basis for creating the framework and makes people dependent on the partly natural and social environment is culture. I can say that there is a culture of human beings in this world who do not know a form of art and tradition.

In society, people learn to recognize and develop their culture. Knowledge of obtaining it is from his experiences in the social life of the various guidance and instruction to obtain it in their communities. But at this time due to the modernization of the cultural behavior of the culture in the world, especially Indonesia which is now just at the last held in the preserve and pious by the parents alone and the younger generation almost no effort to preserve the culture. So what happens now many people especially those students are not familiar with their own culture let alone other cultures are diverse. In Indonesia now many are ending up with western culture forgetting their own culture of Indonesia. Where we will be heading to the Era of disruptions.

College of Indonesia now has a variety of opportunities and challenges in the Age of disruptions. This is to anticipate the development of the world's universities over the next 20-30 years. Universities should be able to overcome the challenges that arise as a result of developments in society. This time we had two incredible disruptions that are the field of technology since the Industrial Revolution 4.0 and Lifestyle for their generational change. 4.0 Industrial Revolution led to the disruption in various fields are on challenges and opportunities included for the millennial generation.

The development of human civilization is accompanied by the development of the delivery of information (hereinafter known by the term information technology). Information and Communication Technology has grown along with globalization, so the interaction and information sharing will take place quickly. Can not deny that technology has a very important role in human life. Through the medium of the media that we can learn the culture and noble values of our nation. Web-based learning is a learning activity that utilizes media websites (Website) which can be accessed through the Internet. Learning media is one component in the learning process that is created as a teaching aid [1].

Youtube is one of the many social networking sites that are widely used today is also very practical learning methods and easy to understand, but in search of the current literature does not make the information that is found on Youtube as a reference. In the Youtube enter it into the field of education is easy and User-Friendly to improve the skills of cooperation and integrate technology into teaching activities. Youtube through the learning process more practical OnLine simply by inserting the URL of the video on the Youtube site to be selected, students can make the account to display in the classroom.

Youtube is a web-based file-sharing services, video that allows a student to be able to download videos that can be shared with others in social relationships upon learning conditions. Youtube utilization as a learning medium to condition students to learn independently "Through 
Independent Study, students Become Doers, as well as thinkers" (Cobine, 1997). As stated in Law No. 14 on public disclosure, stating that every person has the right to communicate and obtain information, develop personal and social environment, and the right to seek, obtain, possess and store information using all available channels. Learn the culture of the archipelago which is packed with technology and the use of social media will change the image and the view of the culture itself. Learning Technology using the web or social media such as Youtube has been known for years by the countries of the world, especially America. Youtube was founded in February 2005. So with just sat facing the computer and connected to the Internet, only students can know theoretically Indonesian culture which evolved into curiosity and lead to an interest in learning about and preserve it. Youtube is the third most visited site in the world after Google and Facebook [3].

Interest utilizing Youtube as a medium of learning is to create conditions and atmosphere of learning interesting, fun and interactive. And can be used at any time without being limited by space and time through the online and offline presentation. And is expected to use Youtube media is also expected that students can make the work of his best and beneficial for the nation, for example by introducing local culture through a video blog, or vlog uploaded via Youtube.

Youtube is an online video and foremost of these is the site's usability as a medium to search, view, and share original videos to and from all corners of the world through a web (Budiargo, 2015: 47). Youtube as collateral that can be used in learning activities. The use of interactive video like Youtube into the learning process will increase understanding and mastery of skills learners [2]. Youtube can be a tool for students to understand the material - material that is abstract to facilitate the understanding of the students during the learning process. Youtube phenomenon as media educational video-based applications in the digital age has been widely made a means to optimize learning.

Youtube one of the applications available on the Internet such as a knife. Why Knives? Because of knives if it is held by the mother - a housewife can produce special dishes, but if it is held by criminals could have impact damage. Likewise for students when it is in use for learning is very helpful, but if misused it will make students the wrong direction because of the use of media in Youtube to watch things like pornography. So I as a principal education need to participate in the competition contain a charge of quality on the internet. It is time for educators to utilize youtube in learning not only to look for a video but also for video upload videos that can help students in understanding the lecture material. Likewise for students when it is in use for learning is very helpful, but if misused it will make students the wrong direction because of the use of media in Youtube to watch things like pornography. So I as a principal education need to participate in the competition contain a charge of quality on the internet. It is time for educators to utilize youtube in learning not only to look for a video but also for video upload videos that can help students in understanding the lecture material.

Likewise for students when it is in use for learning is very helpful, but if misused it will make students the wrong direction because of the use of media in Youtube to watch things like pornography. So I as a principal education need to participate in the competition contain a charge of quality on the internet. It is time for educators to utilize youtube in learning not only to look for a video but also for video upload videos that can help students in understanding the lecture material. One of the uses of Youtube is to be used as a learning media. The purpose of learning Youtube as a medium of learning is to create conditions and atmosphere of learning that is 
interesting, fun and interactive. Learning videos on Youtube can be used for interactive learning in the classroom, both for students and teachers themselves through presentations online and offline [5].

The teachers need to develop a range of skills needed to make a video as a medium of learning. Starting from analyzing the curriculum to determine what appropriate material to be developed using video, skills take pictures (shooting), video editing skills (video editing) to upload on Youtube techniques. The whole skill of skills is not difficult, just need to learn skills and in use over time. In my research with students working to create a channel on Youtube that contains material anthropology especially in culture. With the using Youtube instructional media while learning.

The study used was instructional video development method using an object of research is the students who are taking courses Antropologi. According to Sugiyono in his methods of research and development is the research methods used to produce a specific product and test the effectiveness of these products is not always the product shape objects or equipment (hardware) such as books, modules, teaching aids in the classroom or in the laboratory, but it can also be a software (software) such as computer programs, learning or model of learning model as for the products developed are Video anthropology optimized into media-based educational video Youtube ..Stages that will be done in optimizing the development of this educational video into three stages, namely the preliminary study stage, the stage of drafting the products, and the development stage of evaluation.

\section{Result and discussion}

Development of instructional videos According to Munir (2013: 289), the word video comes from the Latin is Vidi or vise which means seeing or have a vision of data. Video is also a part that emits an image on a television program, "such as sender-tech electronic signals from a moving image. Video is the technology of recording, processing, storage, movement, and construct a sequence of still images. Through the presentation of scenes in the electronic motion. According to Agnew and Kellerman (in Munir, 2013; 290), video as digital media showing the arrangement or sequence of images, through illusion and fantasy in a moving image. Based on the opinion of experts on can he concluded that the video is a medium channeling messages or information, including multimedia objects.

At the time of the lecture in Medan State University Department of History Education in particular during lectures are conventional lectures in each room classroom using blackboard and powerpoint media. It does not provide an opportunity for students to gain access to learning in the classroom. So make the lectures become monotonous and less interactive lectures. At this stage, the researchers gave questionnaires to knows early as the first step state of research subjects related to the theme of the research. Here are the results of recapitulation questionnaires given to students.

Based on the results of early-stage research that was obtained from questionnaires were given to students in the fourth grade with the number of students 110 people then obtained the result that $80 \%$ of time at the finish by the students to use the internet as much as more than 4 hours each 
day, further apart the students conduct WhatsApp, facebook and others can reach $90 \%$ prefer compared to open Youtube and website, the three open a video associated with entertainment is the largest selection chosen by the respondents when open Youtube. While educational video and sports amounted to only $10 \%$ and $5 \%$. Fourth, if $75 \%$ said rarely open educational videos and $25 \%$ who often open educational videos. Furthermore, the researchers conducted the drafting of the mini video product research Anthropology courses by taking the material culture of the Elements. Making the video is done by using storyboards since the beginning of the video display, content to see the cover. Figure 1, 2, and 3 below is the task of the student with observations in fields.

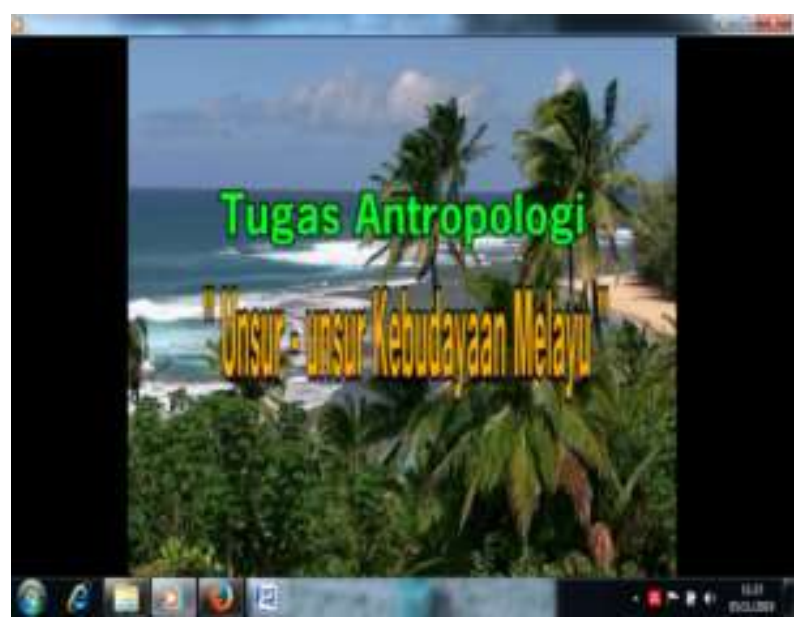

Fig. 1. Display video draft student assignment title

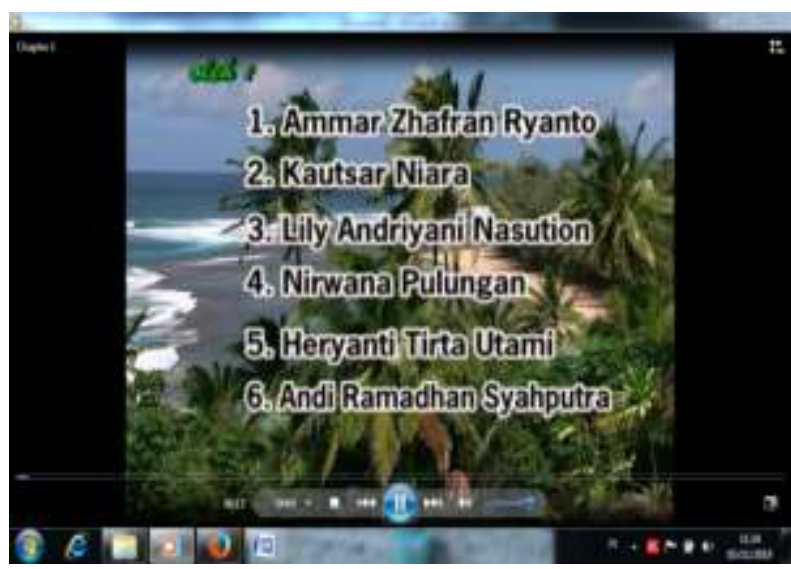

Fig. 3. Display video draft study members 


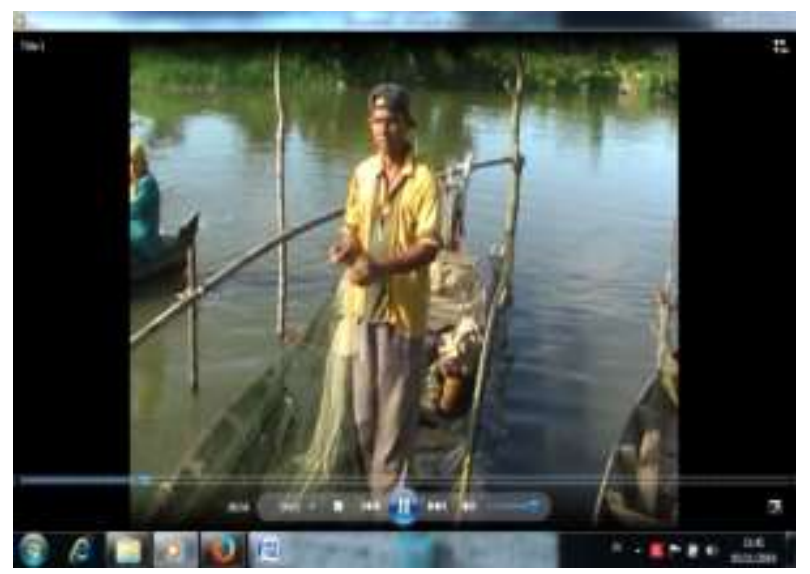

Fig. 3. Display draft one of the activities included in the cultural elements of the system of subsistence

Figure 1, 2 and 3 is an activity undertaken by students including the research into the elements of culture. In this video the researchers conducted interviews with fishermen whose livelihood system is a Malay tribe, with the study participant observation that students are the students participate directly in the activities/participation as fishermen there, students can interact with the fishermen. All views are shown in Figure 2 to 4 are conveyed students to lecturers to provide advice and revision as the first step of making the product. Furthermore, researchers conducted a study of video product improvements to hereinafter will be uploaded to Youtube media.

Furthermore, after the drafting of video products, the students will do a test video to faculty and other students by giving students a questionnaire to evaluate the response to the video is presented which contains two questions and a video advice column of the results. From the results of the questionnaire, the results of student evaluations related to the broadcasting of the video lessons in getting $85 \%$ of students expressed an interest in the video that is designed and displayed. Among the advice column of the students, there are some comments that most appear include: (1) his videos are very nice kind of image and sound, and (2) in interviewing, highly interactive student to society it is so that people feel comfortable.

With the design of the website, according to Jovan (2007) website is a page of information provided via the Internet that can be accessed throughout the world for the website can still be accessed and connected to the Internet network. In presenting the zoom, the website has refractive components under the wishes of the user to create such as displaying images, text, sound, video, and animation. The website as a means of communication and learning media in the study of dynamic websites. Dynamic website means that the website is structured intended for biases efforts updates as often as possible. So the website owner can make changes for the improvement of the content, look and update the all program. The next step in designing instructional video website, Researchers require programming languages and software in the preparation of the Website. At this stage designed website addresses, https://docs.google.com/presentation/ website 
content has been equipped with features. Every student task sends with Gmail. The stages are (1) Log in https://docs.google.com/presentation/ using the Gmail account, (2) click the Add to start the document. See Figure 4 below.

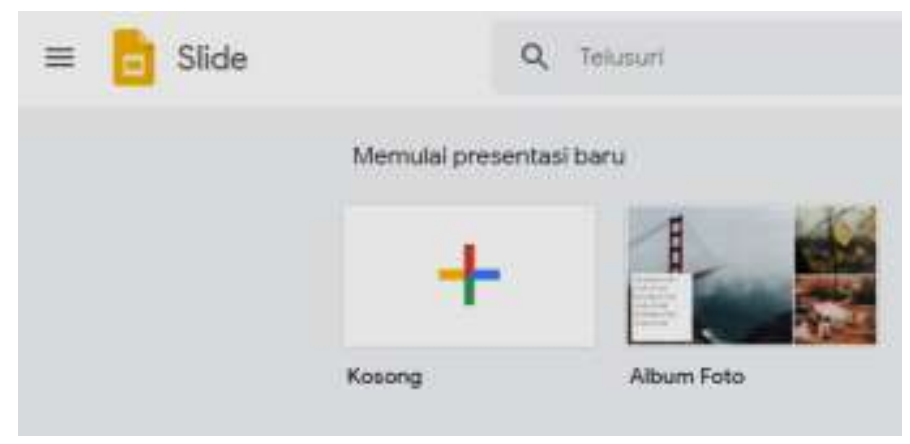

Fig.4. The website for students task collecting

Furthermore, send an email to the email address: antropologijps123.luarbiasa@blogger.com. Every student must be (1) click "File $\rightarrow$ import Slides $\rightarrow$ Upload $\rightarrow$ Select the file from your device, and (2) once you open the PPT file, on page Import Slides, click on all the slides, and then at the bottom click import slides. See Figure 5 below.

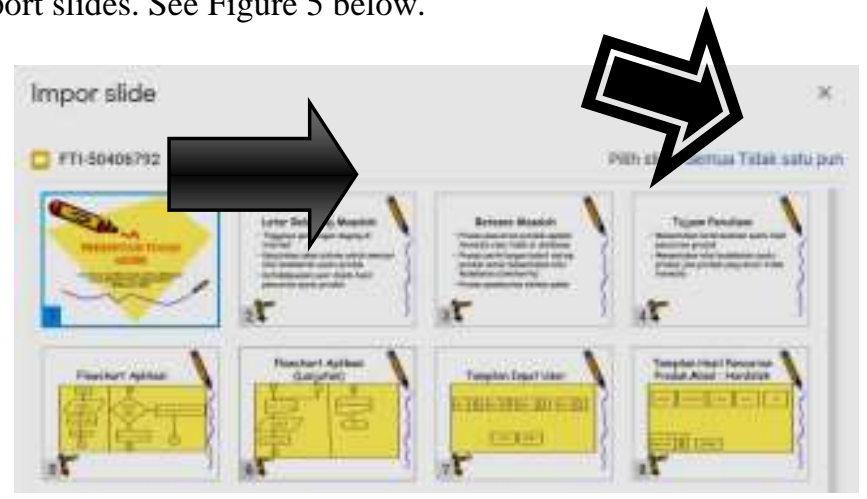

Fig. 5. Page for students task import slides

Once the file is open, click "File $\rightarrow$ Publish to Web", Navigate to the tab" Embed $" \rightarrow$ Publish $\rightarrow$ Ok. See Figure 6 below. 


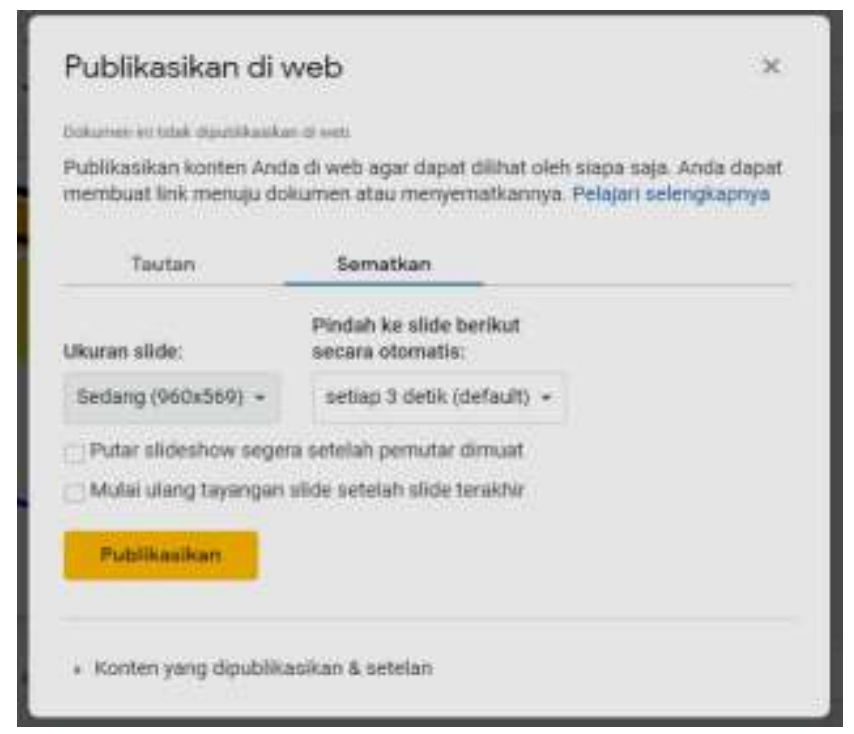

Fig. 6. Page of student task publish

After Ok, will appear on the embed code blocks all the code that is in the bottom box and then "copy". Open Gmail and create a new message, click the + sign to compose a new message, then follow the directions as shown in Figure 8 below

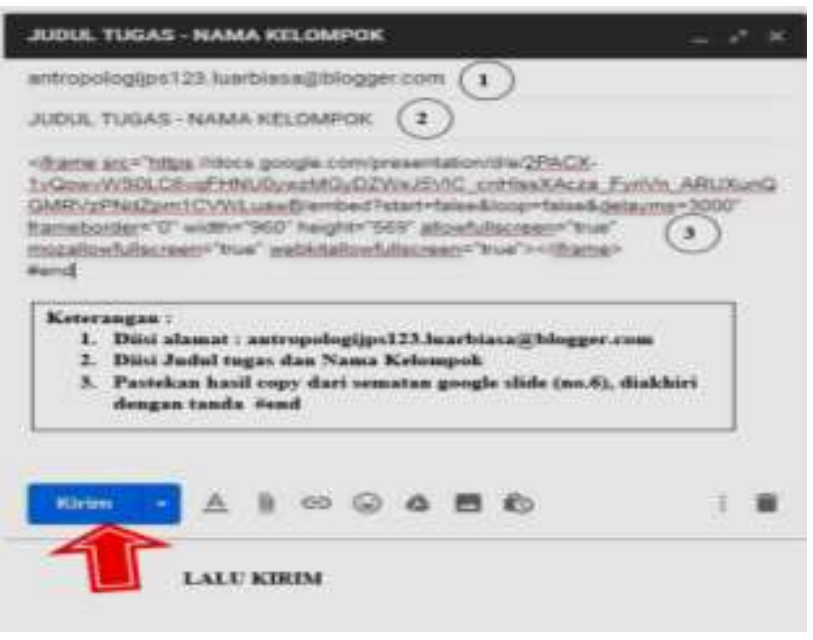

Fig. 8. New message on the student task 
Furthermore, upload video to Youtube: (1) entered into www.Youtube.com, (2) log in with your Gmail account, (3) in the right corner of your Youtube account click, and the (4) click "your channel, and then click the "Upload Video". See Figures 9 and 10 below.

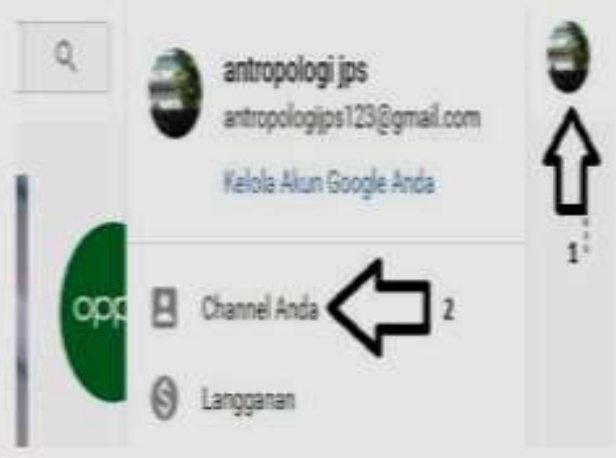

Fig. 9. Customize channel

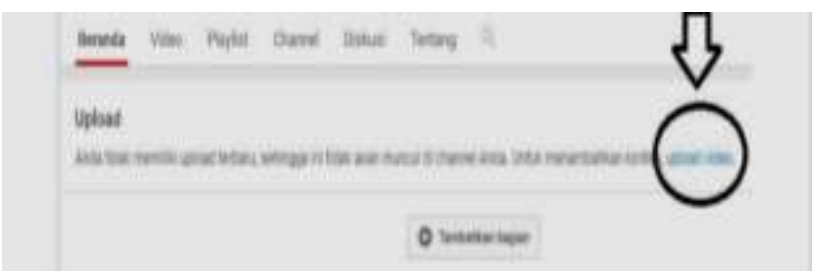

Fig. 10. Upload videos.

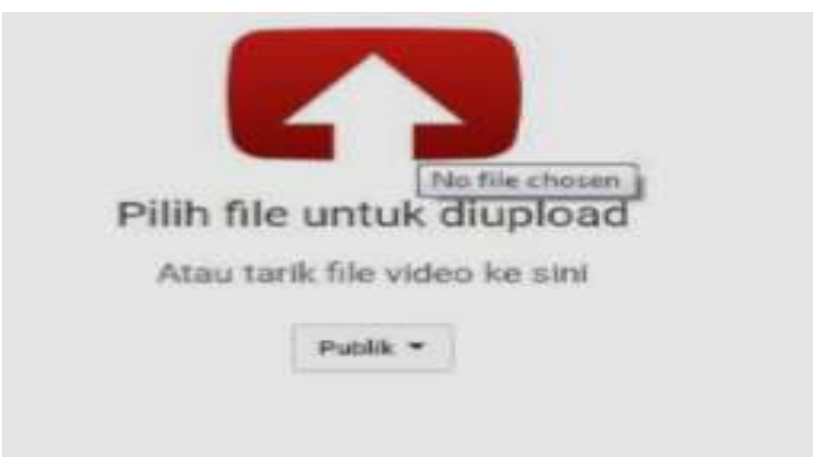

Fig. 11. Choosing the file to upload 
Furthermore for the next steps is: (1) then came the window to select a video to upload, (2) select video to upload, (3) fill in the title of your video with: TITLE VIDEO - GROUP NAME, (4) description Fill with your Video Title, Name, NIM, classes, courses etc., (5) give tag \#antropologijps, (6) click publish, (7) then click embed, copy the embed code, and (8) Open Gmail and create a new message, click the + sign to compose a new messages. See Figures 12 and 13 below.

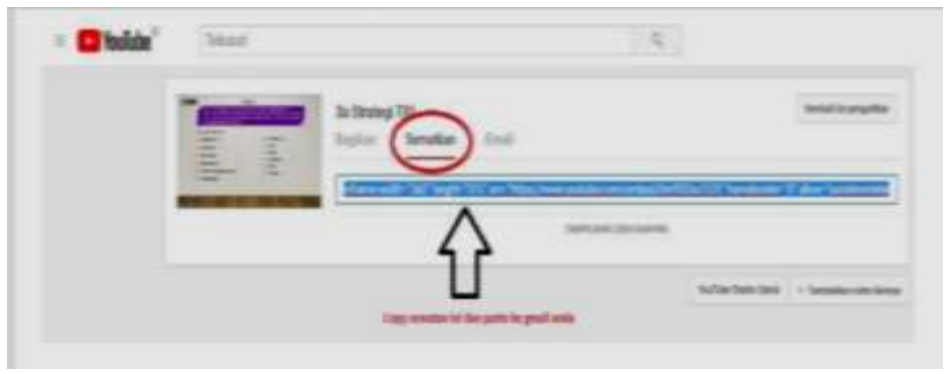

Fig. 12. The title of student task

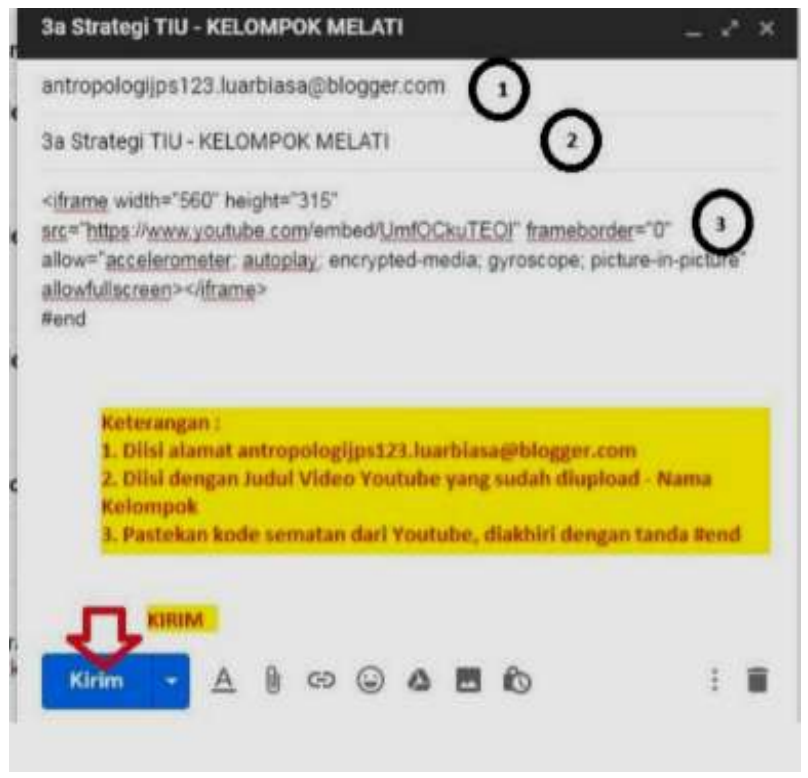

Fig. 13. Final steps of student task collection base on Youtube 


\section{Conclusion}

Based on the research results Optimization of Media Youtube Video-Based Education in learning Increased Anthropology Department of History Education In FY 2019/2020, the researchers concluded that: (1) most respondents stated that by uploading instructional videos Youtube media anthropology to this very well, (2) assessment of students to the content, appearance and usability website showed a positive response so that it will encourage other students to learn about the website, (3) video learning in the show is already perfect both in terms of video image and sound are produced when the video starts, and (4) this website has the potential to continue to be developed to address the needs of students and lecturers of the nonconventional forms of learning.

\section{References}

[1] Ainina, Indah ayu. (2014). Pemanfaatan Media Audio Visual Sebagai Sumber Pembelajaran Sejarah. Indonesian Journal of History Education, 3, 40-45.

[2] Burnett, M. (2008). Integrating Interactive Media Into the Classroom: Youtube Raises The Bar on Student Performance.

[3] Moghavvemi et al. (2018). Social media as a complementary learning tool for teaching and learning: The case of Youtube. The International Journal of Management Education, 16, 34-42.

[4] Ngafifi, M. (2014). Kemajuan Teknologi dan Pola Hidup Manusia Dalam Perspektif Sosial Budaya. 2,34 .

[5] Sukarni. (2012). Memanfaatkan Youtube Sebagai Media Pembelajaran yang Interaktif, Menarik dan Menyenangkan. 